\title{
GOVERNMENT SCIENCES
}

\section{CITY BRAND AND CITY DEVELOPMENT AGENCY: INTERCONNECTION AND CURRENT SITUATION IN UKRAINE}

\section{Balashov Dmytro ${ }^{1}$}

DOI: https://doi.org/10.30525/978-9934-571-89-3_51

For today, city branding is becoming a popular tool for improving the image and competitiveness of the city. Orientation of the city brand to external stakeholders helps to increase the tourist and investment attractiveness. However, using an effective city brand it can be also possible to address important local issues and meet the needs of domestic stakeholders, the main ones being the local population and entrepreneurs.

In order to create a city brand and monitor performance indicators that affect the level of socio-economic welfare of the local population, it is necessary to create special institutions or organizations. They can exist as structural and functional units of the local government or as non-profit organizations.

For example, one of the most successful examples of such an organization is a non-for-profit private company limited by guarantee (LBG) London \& Partners, which was established in 2011 at the initiative of Mayor of London and business partners. The purpose of this institution is to create the brand of London and support its image and development of some specific sectors, in which London can be competitive. The institution operates within the Greater London Authority (GLA). The organization primarily promotes London on the international level in accordance with the strategic priorities of the Mayor's Economic Development Strategy for London. Nevertheless, considering that only in 2017-2018 London \& Partners managed to attract to the city economy $£ 392$ million and provided 7,343 locals with jobs [3], the author can be argued that despite the external orientation, the ultimate goal of the company is still to increase the socio-economic welfare of the local population, which is one of the important tasks of the city branding.

If we look at the current situation in Ukraine, in the conditions of decentralization, regions and cities are also interested in creating their own brands. Taking into account that one of the conditions for the effective implementation of the city's brand in Ukraine is "the presence in a local authorities a special profile structural unit for the effective management of the city's brand and control over all stages of its formation and implementation" [1, p. 137], the issue of the creation, development and positioning of city development agencies, in which city brand can be created,

\footnotetext{
${ }^{1}$ National Technical University of Ukraine "Igor Sikorsky Kyiv Polytechnic Institute", Ukraine 
becomes very relevant. Some studies clearly indicate that city branding can be one of the functions of such agencies [2].

One of the conditions that makes it possible to create and operate city development agencies is the availability of regulatory and legal support. For today, in Ukraine accepted the Cabinet of Ministers Decree No. 285 of November 11, 2016, which called "On Approval of the Model Regulations on the Regional Development Agency" (in Ukrainian: "Pro zatverdzhennja Typovogho polozhennja pro aghenciju reghionaljnogho rozvytku"). It cannot be considered as the basis for the regulation of the activities of the city development agencies, since it is aimed at the regional level, but other provisions and documents, which concerning to the city development agencies, may be based on it.

Despite the lack of clear regulation of the activities, functions and tasks of the city development agencies, such institutions have already been established in Ukraine. They are include the following city development agencies as: Mykolaiv Development Agency, Bila Tserkva Strategic Development Agency, Municipal Institution "City Development Agency" of Zhytomyr City Council, Melitopol Development Agency, Dnipro Development Agency, Municipal Institution of the Khmelnytsky City Council "Khmelnytsky Development Agency" etc.

One of the cities in Ukraine, which, according to the author, is the most advanced in issues of the formation and development of the city brand, is Lviv. The function of the city development agency in Lviv is assigned to a special municipal institute, which focuses also on the city branding issues - the Institute of the City (in Ukrainian: Instytut mista). This institution is positioned as an analytical center of communal ownership with a non-profit status and is subject to the executive committee of the Lviv City Council.

The purpose of the activity of this institution is to unite efforts of the local government, residents and entrepreneurs of Lviv to solve the key issues of strategic development and city branding. Expert groups conduct a thorough analysis of the processes of strategic development and, on the basis of it, formulate and correct the concept of branding. The Lviv City Institute coordinates the implementation of the "Integrated Strategy for the Development of Lviv", "Lviv Competitiveness Strategy" and develops other sectorial strategies ("Lviv Strategic Investing Plan", "Lviv Strategy for the Development of Culture", etc.). The Institute of the City is also actively cooperates with international institutions of city branding and urban development to solve current city problems.

Due to the City Institute, in comparison with other Ukrainian cities, Lviv has the largest number of documents of strategic and branding issues, which allow to bring Lviv to the higher level of interaction with different groups of stakeholders. The most important of these documents is the "Complex Development Strategy of Lviv 2012-2025", which clearly establishes the methodological basis for the creation of this document, conducted a detailed analysis of previous development strategies, taking into account their advantages and compensations for deficiencies, formed the strategic vision and objectives of conceptual development, and fixed the mechanism of organization and monitoring of the city development strategy. An important point 
of this document is the definition of the city's visions from the point of view of the locals and defining development priorities of the city, which makes it possible to consider this document as the basis for the Lviv city brand.

As follows, it can be noted that in Ukraine, the city development agencies are already actively establishing and operating. Their presence accelerates the formation of more effective city brands. Despite this, there is a burning issue in regulating the activities of such institutions and approval of regulatory and legal documents. Also, it is expedient for local authorities in Ukraine to study and reapply the successful experience of the activities of the city development agencies, whose functions should include formation and development of the city brand.

\section{References:}

1. Balashov D. (2019). Peredumovy efektyvnogho vprovadzhennja brendu mista v Ukrajini: derzhavno-upravlinsjkyj aspect [Prerequisites of effective implementation of the city brand in Ukraine: state-administrative aspect]. Investytsiyi: praktyka ta dosvid, vol. 5, pp. 134-137. DOI: 10.32702/2306-6814.2019.5.134.

2. Jak stvoryty zhyttjezdatnu aghenciju misjkogho rozvytku. Praktychnyj posibnyk dlja ukrajinsjkykh mist ta rajoniv [How to create a viable city development agency. Practical guide for Ukrainian cities and districts]. Retrieved from: http://regionet.org.ua/files/How_to_ establish_sustainable_local_development_agency_UNDP_2013_ua.pdf (accessed 02 April 2019).

3. London \& Partners Annual Report 2018. Retrieved from: https://files.londonandpartners.com/ 1-and-p/assets/annualreview201718.pdf (accessed 03 April 2019). 